\title{
Research on Customer Perception Value of Delivery O2O Platform Based on PCA-FUZZY
}

\author{
Jiali Zhao \\ School of Management, China University of Mining and Technology, Beijing, Beijing 100083, \\ China.
}

1091909238@qq.com

Keywords: CPV, Fuzzy, PCA, Delivery, O2O.

\begin{abstract}
In order to scientifically measure the customer perceived value (CPV) of the Online to Offline (O2O) platform, the CPV indicator system of the delivery $\mathrm{O} 2 \mathrm{O}$ platform is constructed from three dimensions which are functional value, service value, and experience value. The various dimensions and indicators are weighted by the principal component analysis (PCA). A fuzzy comprehensive evaluation model of CPV for delivery $\mathrm{O} 2 \mathrm{O}$ Platform is constructed. Taking the $\mathrm{M}$ platform as an example, it is found that the $\mathrm{M}$ platform should focus on the enhancement of customer experience value while maintaining functional value and service value.
\end{abstract}

\section{Introduction}

The delivery $\mathrm{O} 2 \mathrm{O}$ platforms have a high frequency of user consumption and their competition is fierce in China. It is an urgent problem for delivery $\mathrm{O} 2 \mathrm{O}$ platforms to improve customers' satisfaction and loyalty. Therefore, how to increase customers' willingness to use a delivery platform is a valuable issue to be resolved. Clearly, CPV has a significant impact on the customer satisfaction and repeated purchases [1]. It can be seen that the CPV is an important factor to maintain the O2O platform's competitiveness. However, how to measure the CPV of the $\mathrm{O} 2 \mathrm{O}$ platform?

In this paper, a fuzzy comprehensive evaluation model based on CPV indicator system and PCA method is proposed to solve this problem. Furthermore, taking M platform as an example, the data of $\mathrm{CPV}$ is obtained through a questionnaire survey. After a series of calculation, the advantages and disadvantages of $\mathrm{M}$ platform can be obtained. Finally, some management improvement suggestions are summarized.

\section{The Construction of Indicator System}

There are substantial research results for CPV, and in the context of the continuous development of the Internet, many works have researched CPV dimensions for online shopping. Eun-Ju and Jeffrey [3] believed that the CPV under the context of online shopping should be divided into experience value and economic value; Gao Juan et al[4] divided CPV into perceived gains and perceived gains and losses; Gao Yingzhi [5] divided CPV of online restaurant group purchase into three dimensions: economic value, quality value and convenience value; Liu Hongguo [6] divided the CPV of O2O catering platform into four dimensions: result value, procedural value, emotional value, and social value. In summary, according to a comprehensive consideration of predecessors' research, we divide the CPV of the delivery $\mathrm{O} 2 \mathrm{O}$ platform into three dimensions: functional value, service value and experience value. There are several measurement items in each dimension as shown in Table 1.

\section{Investigation}

M platform is taken as research object, and questionnaires are conducted through on-site or online investigation. The validity of the pre-test questionnaire is convincing, followed by a large sample of formal investigations. Finally, 713 valid questionnaires are returned, and the effective rate of the questionnaire is $94.44 \%$. 
Table 1. Indicator system of CPV for delivery O2O platform

\begin{tabular}{|c|c|c|c|}
\hline Target layer & Criteria layer & Indicator layer & Items \\
\hline \multirow{15}{*}{$\begin{array}{l}\text { Indicator System of CPV for } \\
\text { Delivery O2O Platform }\end{array}$} & \multirow{6}{*}{ Functional Value } & Food Safety & The food is safe and reliable \\
\hline & & Food Category & The platform is rich in food \\
\hline & & Food Temperature & It has good food \\
\hline & & - & $\begin{array}{l}\text { insulation/cooling effect } \\
\text { It has reasonably priced }\end{array}$ \\
\hline & & Website Performance & The process is easy and \\
\hline & & Interface Design & The interface is beautiful \\
\hline & \multirow{4}{*}{ Service Value } & Special Service & $\begin{array}{c}\text { The distinctive service is } \\
\text { attractive }\end{array}$ \\
\hline & & Service & $\begin{array}{l}\text { It has a good after-sales } \\
\text { service }\end{array}$ \\
\hline & & Delivery Attitude & The rider has a good attitude \\
\hline & & Delivery Time & $\begin{array}{l}\text { Food can always be delivered } \\
\text { on time }\end{array}$ \\
\hline & \multirow{5}{*}{ Experience Value } & Emotional Value & $\begin{array}{c}\text { It can makes me happy and } \\
\text { relaxed }\end{array}$ \\
\hline & & Time Value & $\begin{array}{l}\text { Booking on this platform } \\
\text { saves my time }\end{array}$ \\
\hline & & Social Value & It can reflect my personality \\
\hline & & Safety Value & The transaction process is safe \\
\hline & & Green Value & $\begin{array}{l}\text { The food packaging is } \\
\text { environmentally friendly }\end{array}$ \\
\hline
\end{tabular}

In order to ensure the validity and accuracy of the scale and data, SPSS21.0 is used to test the reliability and validity, as shown in Table 2.

Table 2. Reliability and Validity Test Results

\begin{tabular}{|c|c|c|c|c|c|c|c|c|}
\hline \multirow{3}{*}{$\begin{array}{c}\text { CPV for } \\
\text { Delivery } \\
\text { O2O }\end{array}$} & \multirow[b]{2}{*}{ Dimensions } & \multirow{2}{*}{$\begin{array}{l}\text { Number } \\
\text { of items }\end{array}$} & \multirow{2}{*}{$\begin{array}{l}\text { Cronbach's } \\
\text { Alpha }\end{array}$} & \multirow{2}{*}{$\begin{array}{l}\text { Cronbach's } \\
\text { Alpha }\end{array}$} & \multirow[b]{2}{*}{ KMO } & \multicolumn{3}{|c|}{ Bartlett's sphere test } \\
\hline & & & & & & $\begin{array}{l}\text { Chi- } \\
\text { square }\end{array}$ & $\mathrm{df}$ & Sig. \\
\hline & $\begin{array}{l}\text { Functional } \\
\text { value }\end{array}$ & 6 & 0.896 & & & & & \\
\hline \multirow[t]{2}{*}{ Platform } & $\begin{array}{l}\text { Service } \\
\text { value }\end{array}$ & 4 & 0.908 & 0.873 & 0.910 & 7371.950 & 105 & 0.000 \\
\hline & $\begin{array}{l}\text { Experience } \\
\text { value }\end{array}$ & 5 & 0.913 & & & & & \\
\hline
\end{tabular}

\section{Analysis}

\subsection{Building Fuzzy Comprehensive Evaluation Factor Set}

The set of target layer is as follows:

The set of criteria layers is as follows:

$$
\mathrm{U}=(\mathrm{U} 1, \mathrm{U} 2, \mathrm{U} 3)
$$

$$
\begin{gathered}
\mathrm{U} 1=(\mathrm{U} 11, \mathrm{U} 12, \mathrm{U} 13, \mathrm{U} 14, \mathrm{U} 15, \mathrm{U} 16) \\
\mathrm{U} 2=(\mathrm{U} 21, \mathrm{U} 22, \mathrm{U} 23, \mathrm{U} 24) \\
\mathrm{U} 3=(\mathrm{U} 31, \mathrm{U} 32, \mathrm{U} 33, \mathrm{U} 34, \mathrm{U} 35)
\end{gathered}
$$

\subsection{Determination of Rating Set}

The evaluation set of the CPV is set $\mathrm{V}$, and the evaluation level is divided into five levels. The larger the number, the better the evaluation.

$$
\mathrm{V}=(\mathrm{V} 1, \mathrm{~V} 2, \mathrm{~V} 3, \mathrm{~V} 4, \mathrm{~V} 5)
$$

The evaluation set $\mathrm{X}$ is quantified and normalized using the formula $y_{i}=\frac{m_{i}-m_{\min }}{m_{\max }-m_{\min }}\left(m_{i}\right.$ indicates the evaluation level), and the quantified set is obtained as follows: 


$$
\mathrm{Y}=\left(y_{1}, y_{2}, y_{3}, y_{4}, y_{5}\right)=(0,0.25,0.5,0.75,1)
$$

The evaluation results of CPV is shown in Table 3.

Table 3. Evaluation Table of CPV

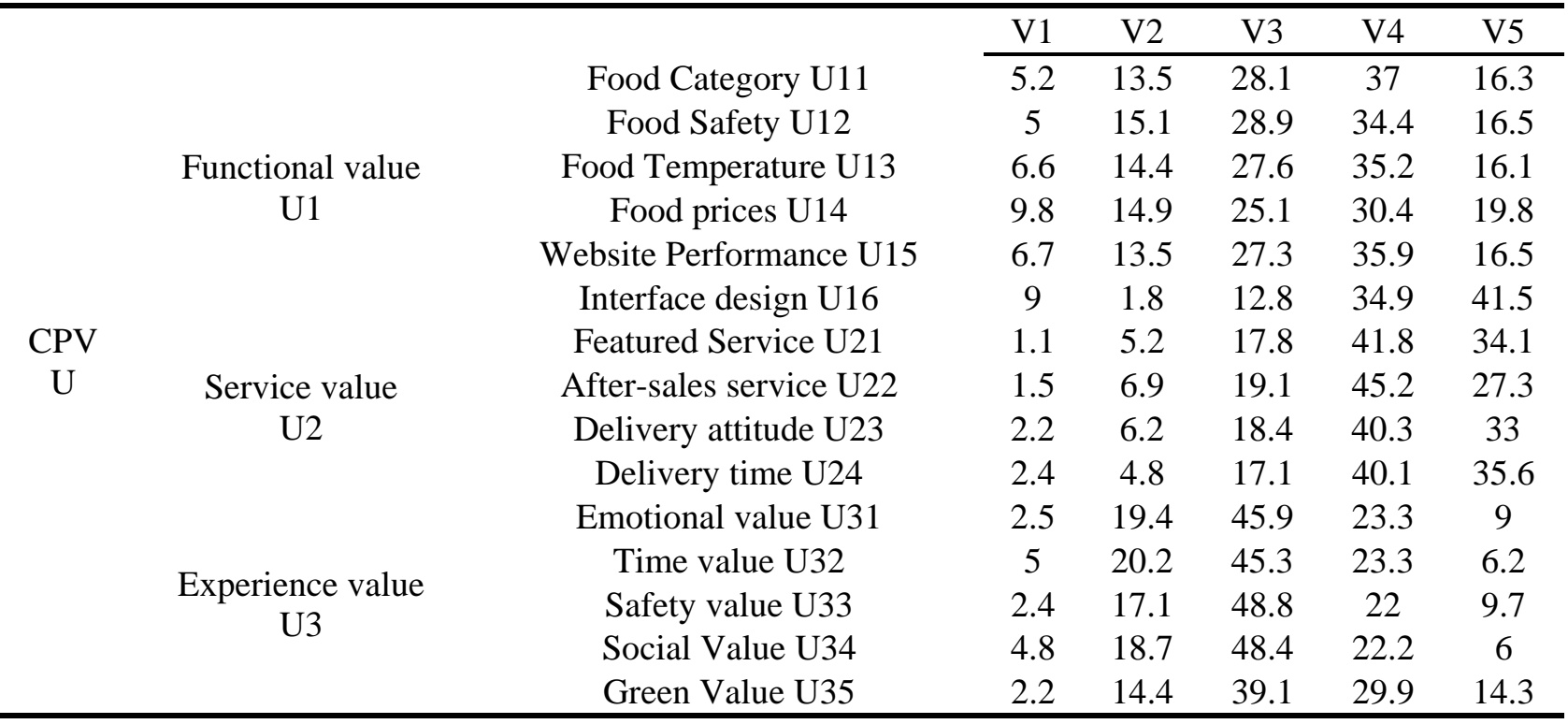

\subsection{Determine the Weight Set of the Evaluation Indicator System}

PCA is used to determine the weights. The indicators' weights of target layer are calculated through the variance contribution rate. After the normalization, the sets of weights as follows:

$$
\mathrm{w}=\left(w_{1}, w_{2}, w_{3}\right)=(0.3652,0.3469,0.2879)
$$

Then the weights of the criteria layer indicators are obtained by using the maximum variance method rotation factor load. After the normalization, their weights are set as follows:

$$
\begin{gathered}
w_{1}=\left(w_{11}, w_{12}, w_{13}, w_{14}, w_{15}, w_{16}\right) \\
=(0.1773,0.1754,0.1722,0.1708,0.1695,0.1348) \\
w_{2}=\left(w_{21}, w_{22}, w_{23}, w_{24}\right) \\
=(0.2615,0.2523,0.2456,0.2405) \\
w_{3}=\left(w_{31}, w_{32}, w_{33}, w_{34}, w_{35}\right) \\
=(0.2119,0.2055,0.2005,0.2001,0.1819)
\end{gathered}
$$

\subsection{The Determination of the Judgement Membership Matrix}

According to the scores of CPV, the membership matrices $R_{1}, R_{2}, R_{3}$ are constructed by three factors: functional value, service value, and experience value. $U_{i j}$ (the j-th sub-factor in the i-th main factor) represents the $\mathrm{k}$-th grade for the evaluation, which is denoted as the membership degree $r_{i j k}$ :

$$
r_{i j v}=v_{j k} / \sum_{k=1}^{5} v_{j k}(i=1,2,3 ; j=1,2 \cdots n ; k=1,2 \cdots 5)
$$

Membership degree matrices are represented as follows:

$$
\begin{aligned}
R_{1} & =\left[\begin{array}{lllll}
0.163 & 0.370 & 0.281 & 0.135 & 0.052 \\
0.165 & 0.344 & 0.289 & 0.151 & 0.050 \\
0.161 & 0.352 & 0.276 & 0.144 & 0.066 \\
0.198 & 0.304 & 0.251 & 0.149 & 0.098 \\
0.165 & 0.359 & 0.273 & 0.135 & 0.067 \\
0.415 & 0.349 & 0.128 & 0.018 & 0.090
\end{array}\right] \\
R_{2} & =\left[\begin{array}{lllll}
0.341 & 0.418 & 0.178 & 0.052 & 0.011 \\
0.273 & 0.452 & 0.191 & 0.069 & 0.015 \\
0.330 & 0.403 & 0.184 & 0.062 & 0.022 \\
0.356 & 0.401 & 0.171 & 0.048 & 0.024
\end{array}\right] \\
R_{3} & =\left[\begin{array}{lllll}
0.090 & 0.233 & 0.459 & 0.194 & 0.025 \\
0.062 & 0.233 & 0.453 & 0.202 & 0.050 \\
0.097 & 0.220 & 0.488 & 0.171 & 0.024 \\
0.060 & 0.222 & 0.484 & 0.187 & 0.048 \\
0.143 & 0.299 & 0.391 & 0.144 & 0.022
\end{array}\right]
\end{aligned}
$$

\subsection{Fuzzy Comprehensive Evaluation}

First fuzzy comprehensive evaluation set $B_{i}(i=1,2,3)$ of the criterion layer is calculated as: 


$$
B_{i}=R_{i} \cdot W_{i}(i=1,2,3) .
$$

The comprehensive model $B_{i}(i=1,2,3)$ is computed according to the general matrix comprehensive multiplication algorithm, and the results are formulated as

$$
\begin{aligned}
& B_{1}=W_{1} \cdot R_{1}=(0.203,0.346,0.254,0.126,0.070) \\
& B_{2}=W_{2} \cdot R_{2}=(0.325,0.419,0.181,0.058,0.018) \\
& B_{3}=W_{3} \cdot R_{3}=(0.089,0.240,0.456,0.181,0.034)
\end{aligned}
$$

Based on the principle of maximum degree of membership, it can be seen that function value, service value, and experience value of $\mathrm{M}$ platform are at the levels of "relatively high", "relatively high", and "average”, respectively.

The comprehensive evaluation set of the target layer is shown in the following formula.

$$
\mathrm{B}=W \cdot R=(0.3652,0.3469,0.2879) \cdot\left[B_{1}, B_{2}, B_{3}\right]^{T}=(0.213,0.341,0.287,0.118,0.0415)
$$

According to the fuzzy distribution method, the percentages of "very high, relatively high, average, relatively low, and very low” are: $21.3 \%, 34.1 \%, 28.7 \%, 11.8 \%$, and $4.15 \%$, respectively. According to the principle of maximum degree of membership, the comprehensive evaluation of perceived value is at the level of "relatively high" for M platform.

According to the percentage system, the comprehensive score of CPV can be quantified as

$$
\mathrm{Z}=\mathrm{Y} \cdot B^{T} * 100=100 * \sum_{i=1}^{5} y_{i} \cdot b_{i}=64.175
$$

It can be seen that the CPV of M platform in the comprehensive customer evaluation is "relatively high”.

\section{Analysis}

If a score of 60 is considered as a qualifying standard, then the M platform is qualified. In its three dimensions: functional values and service values meet standards, but experience values do not. From the perspective of weights, they are $0.3652,0.3469$, and 0.2879 for function value, service value, and experience value respectively. It can be seen that the most important dimension for the customer is the functional value, followed by the service value, and finally the experience value. However, the weight of experience value reaches $28.79 \%$, which is also an important part of CPV. By comprehensively measuring the weights and scoring results, we can conclude that $\mathrm{M}$ platform needs to focus on the enhancement of the customer experience value while the maintaining functional value and service value.

\section{References}

[1]. Zeithaml, V. A. (1988). Consumer perceptions of price, quality, and value: a means-end model and synthesis of evidence. Journal of Marketing, 52(3), 2-22.

[2]. Sheth J.N., Newman B.I., Gross, B. L. Why We Buy What We Buy: A Theory of Consumption Values. Journal of Busi-ness Research, 1991, (22): 159-170.

[3]. Eun-Ju Lee, Jefrey W. Creating value for online shoppers: implications for satisfaction and loyalty. Journal of Consumer Satisfaction, Dissatisfaction and Complaining Behavior. Vol. 17 (2004). p. 54-67.

[4]. Gao Juan, Cui Qian. Research on customer perceived value of B2C network purchase. Business age. 2012(19):35-37.

[5]. Gao Yingzhi. The Impact of Customer Perceived Value on Decision-making in Consumer Internet Catering Groups. Xiangtan University, 2015.

[6]. Jun li. Empirical Research on Brand Loyalty Model Building of Cigarette Products Based on Customer Perceived Value. Business economy. Vol. 30(03). (2011). p. 54-67. 